\title{
Assessment of Genetic Variability, Heritability and Genetic Advance in Chrysanthemum (Dendranthema grandiflora Tzvelve)
}

\author{
Mallikarjun Hebbal $^{1 *}$, Mukund Shiragur ${ }^{1}$, Mahantesha B.N. Naika ${ }^{2}$, \\ G.K. Seetharamu ${ }^{1}$, Sandhyarani Nishani ${ }^{2}$ and B.C. Patil ${ }^{1}$ \\ ${ }^{1}$ Department of Floriculture and Landscape Architecture, University of Horticultural \\ Sciences, Bagalkot, Karnataka, India \\ ${ }^{2}$ Department of Crop Improvement and Biotechnology, KRCCH, Arabhavi-591218, University \\ of Horticultural Sciences, Bagalkot, Karnataka, India \\ *Corresponding author
}

A B S T R A C T

Ten genotypes of chrysanthemum were evaluated under naturally-ventilated polyhouse in Completely Randomized Block Design during the year 2017-18 to determine genetic

\section{Keywords}

Chrysanthemum, genetic variability $(\mathrm{GCV}, \mathrm{PCV})$ heritability, genetic advance (GAM)

Article Info

Accepted: 26 July 2018 Available Online: 10 August 2018 variability, heritability and genetic advance for different quantitative and qualitative traits, based on which selection may be made. Analysis of Variance showed significant differences among genotypes for all the characters studied. Results revealed that magnitude of the Phenotypic Coefficient of Variation (PCV) was higher than Genotypic Coefficient of Variation (GCV) for all the traits, indicating genotype and environment interaction. High (>20\%) PCV and GCV was observed for number of secondary branches, number of leaves, leaf area, stem girth, days to flower bud initiation and days to first flowering. Heritability estimates ranged from a moderate $55.10 \%$ (number of secondary branches/plant) to high as $99.74 \%$ (Days to flower bud initiation). High heritability (>60\%) was observed for all traits except number of secondary branches/plant. Estimates of high heritability coupled with high genetic advance as per cent of mean (GAM) were observed for all the growth, flowering, yield and quality parameters studied indicating the possible role of additive gene action.

\section{Introduction}

Flowers and flowering plants are fascinating part of our life. Among them, chrysanthemum (chryos - golden; anthos - flower) called as "Queen of the East" is a most interesting and popular flower crop of commercial importance. It ranks third in the International cut flower trade next to rose and carnation in demand and popularity. Chrysanthemum is native to China, belonging to the family Asteraceae which is the most phylogenetically advanced dicotyledonous family. The inflorescence is called as capitulum or head consisting of large number of tiny florets closely mounted on a flattened stem end, which gives a false appearance of single bloom. Garden chrysanthemum which was previously known as Chrysanthemum morifolium (Ramat) and now it is called as 
Dendranthema grandiflora (Tzvelev) Kumbar et al., (2017). In India chrysanthemum commercially cultivated in states like Tamil Nadu, Karnataka, Maharashtra, Rajasthan, Madhya Pradesh and Bihar. Its cultivation is popular around the cities like Delhi, Kolkata, Lucknow, Kanpur, Chennai, Allahabad and Bengaluru. It is grown in an area of 5,453 ha with production of 59,543 Mt and productivity of $10.92 \mathrm{t} / \mathrm{ha}$ in Karnataka state for loose flower purpose (Anon., 2016). Still, there is a need to increase chrysanthemum cultivation which is limiting due to lack of high yielding varieties with attractive flowers.

The phenotypic expression of the plant character is mainly controlled by the genetic makeup of the plant and the environment in which it is grown plus the interaction between the genotypes and environment. Further, the genotype of the plant is controlled by different gene action i.e. additive gene effect (heritable), non-additive gene effect or dominance (non-heritable) and epistasis (nonallelic dominance).

Therefore, it becomes necessary to partition the observed phenotypic variability into its heritable parameters such as coefficient of variation, heritability and genetic advance Panse and Sukhatme (1967). Hence, a study was conducted to evaluate the genetic variability, heritability and genetic advance of different chrysanthemum genotypes.

\section{Materials and Methods}

The experiment was conducted to study the genetic variability, heritability and genetic advance of different genotypes of chrysanthemum (Dendranthema grandiflora Tzvelve). The experimental material comprised of ten chrysanthemum genotypes such as Marigold, Dall White, Karnool, Dall Yellow, Poornima Yellow, Poornima Pink, Calcutta Shantini, Poornima Red, Poornima
White and Dundi. The genotypes were evaluated in Complete Randomized Design with three replications during kharif 2017-18 at K. R. C. College of Horticulture, Arabhavi. The plants were planted at a spacing of $60 \mathrm{X}$ $45 \mathrm{~cm}$ and all the recommended cultural practices were followed. Five competitive plants were tagged at random in each treatment in each replication for recording detailed observation and the data were recorded for all the 19 quantitative and qualitative characters viz., plant height, number of primary and secondary branches, number of leaves at 90 days after planting, leaf area $\left(\mathrm{cm}^{2}\right)$, stem girth, days taken for flower bud initiation, days to first flowering, days for 50 per cent flowering, duration of flowering (days), number of flowers per plant, individual flower weight $(\mathrm{g})$, hundred flowers weight $(\mathrm{g})$, diameter of flower $(\mathrm{cm})$, shelf life (h) and flower yield per plant (g/plant) were recorded. Mean values were subjected to analysis of variance, genotypic and phenotypic coefficient of variation were estimated based on estimate of genotypic and phenotypic variance (Burton and Devane.,1953, broad sense heritability was calculated as ratio of genotypic variance to phenotypic variance and expressed in percentage, genetic advance was calculated using formula given by Robinson $e t$ al., (1949), genetic advance as per cent over mean was worked out and categorized as suggested by Johnson et al., (1955).

The present investigation was carried out using ten genotypes of chrysanthemum to assess the extent of genetic variability and diversity based on morphological basis. Further, the genetic components like genotypic coefficient of variation (GCV), phenotypic coefficient of variation (PCV), heritability (broad sense), genetic advance (GA) and genetic advance as per cent mean (GAM) studies were also conducted for growth, flowering, yield and quality parameters. 
The range in the values reflect the amount of phenotypic variability, which is not very reliable since it includes genotypic, environmental and genotype $\mathrm{x}$ environmental interaction components and does not reveal as to which character showing higher degree of variability. Further, the phenotype of the crop is influenced by additive gene effect (heritable), dominance (non- heritable) and epitasis (non- allelic interaction). Hence, it becomes necessary to work out the observed variability into phenotypic coefficients of variability (PCV) and genotypic coefficients of variability (GCV), which ultimately indicate the extent of variability existing for various traits. However, even this does not give a true picture about the extent of inheritance of the character.

The effectiveness of selection for any character does not depend on the amount of variability alone but also with estimates of heritability. It is of great interest to the plant breeder to determine how much of the phenotypic variability which is present in a particular generation is heritable and the accuracy with which a genotype can be evaluated by its phenotypic expression. Therefore, the heritability $\left(\mathrm{h}^{2}\right)$ of a character can be relied upon, as it enables them to decide the extent of selection pressure to be applied under particular environment, which separate out the environmental influence from the total variability. Nevertheless, its use would be limited as this is prone to changes in environment, material, etc. The estimation of heritability has a greater role to play in determining the effectiveness of selection of a character provided it is considered in conjunction with the predicted genetic advance as suggested by Johnson et al., (1955) and Panse and Sukhatme (1967). Since, heritability is influenced by bio-metrical method, generation of hybrid, sample size of experimental material and environment (Hanson, 1963).
Heritability $\left(\mathrm{h}^{2}\right)$ and genetic advance over per cent mean (GAM) varied for growth parameters. Higher heritability indicates the effectiveness of selection through phenotypic performance, but it does mean a high genetic gain. The magnitude of heritable variability is the most important aspect of the genetic constitution of breeding material. However, high heritability associated with high GAM proves more useful for efficient improvement of a character through simple selection (Panse and Sukhatme, 1967).

\section{Results and Discussion}

Assessment of genetic variability and genetic diversity based on morphological traits

\section{Analysis of variance}

The analysis of variance for different quantitative characters revealed significant $(\mathrm{P}=0.05)$ differences among the genotypes for all the growth parameters, flowering, yield and quality parameters.

\section{Genetic variability}

To understand the extent of the observed variations due to genetic factors, viz., the genotypic coefficient of variation (GCV), phenotypic coefficient of variation (PCV), broad sense heritability $\left(h^{2}\right)$, genetic advance (GA) and genetic advance as per cent of mean (GAM) were studied (Fig. 1). The Data revealed the existence of large amount of variability with respect to all characters studied as given in Table 1.

\section{Growth parameters}

The estimates of moderate genotypic and phenotypic coefficient of variations for plant height at 90 days after planting were 15.57 per cent and 17.67 per cent, respectively. The high heritability $(77.70 \%)$ was observed for plant 
height with moderate genetic advance as per cent of mean $(28.27 \%)$. The estimates of genotypic coefficient of variations for number of primary branches at 90 days was moderate 19.60 per cent and phenotypic coefficient of variation was high 24.44 per cent respectively.

The high heritability and high genetic advance as per cent of mean were 64.30 per cent and 32.36 per cent respectively for this trait.

The estimates of genotypic and phenotypic coefficient of variations for number of secondary branches at 90 days were high as 33.97 and 45.76 per cent respectively. The moderate heritability and high genetic advance as per cent of mean $(55.10 \%)$ and $(51.96 \%)$, respectively were observed.

Numbers of leaves per plant at 90 days showed high estimates of genotypic and phenotypic coefficients of variations (70.95 per cent and 71.92 per cent respectively). Whereas, high heritability of 97.30 per cent was observed with high genetic advance as per cent of mean $(94.78 \%)$.

Plant spread in East-West direction at 90 days after planting showed high estimates of genotypic and phenotypic coefficient of variations 21.21 per cent and 22.80 per cent, respectively. The high heritability $(86.60 \%)$ was observed for plant spread with high genetic advance as per cent of mean $(40.66 \%)$.

Plant spread in North- South direction at 90 days after planting showed moderate genotypic and high phenotypic coefficient of variations 16.95 per cent and 20.17 per cent, respectively. The high heritability $(70.70 \%)$ was observed for plant spread with high genetic advance as per cent of mean (29.35\%).

The genotypic and phenotypic coefficients of variations of leaf area were high as 32.66 per cent and 33.95 per cent respectively. High heritability 92.60 per cent coupled with high genetic advance as per cent of mean $(64.73 \%)$ was observed for this trait.

The genotypic and phenotypic coefficients of variations for stem girth of the plant were high 22.60 per cent and 23.29 per cent, respectively. High heritability (94.20\%) coupled with high genetic advance as per cent of mean $(45.19 \%)$ was noticed for this trait.

The coefficients of variations for both the genotypic and phenotypic for growth parameters revealed that the low differences were observed for number of primary, secondary branches and number of leaves, plant spread in E-W and N-S (at 90 DAP), stem girth and leaf area thus suggesting the major contribution of genetic variability towards the total variance indicating ample scope for improvement. Similar trend was reported in chrysanthemum for all the characters was noticed and as reported by Chaugule (1985); Shiragur (2009) and Kore (2014) in China aster.

In present study, estimates of high heritability with high genetic advance over per cent mean (GAM) were observed for plant height, number of primary and secondary branches per plant, number of leaves per plant, leaf area and stem girth indicating the possible role of additive gene action. The results are in conformity with observation made by Negi et al., (1983) and Kore (2014) for plant height in China aster, number of leaves per plant (Kannan and Ramdas, 1990) in gerbera and in chrysanthemum by Talukdar et al., (2003) and Shiragur (2009).

\section{Flowering parameters}

High estimates of GCV (21.05\%) and PCV $(21.09 \%)$ coupled with high heritability $(99.74 \%)$ and high genetic advance as per cent of mean (43.18\%) observed for days to flower bud initiation. 
Table.1 Genetic estimates for various growth, flowering, yield and quality parameters in chrysanthemum

\begin{tabular}{|c|c|c|c|c|c|}
\hline Sl. No. & Character & GCV $(\%)$ & PCV (\%) & $\mathbf{h}^{2}(\%)$ & GAM (\%) \\
\hline \multicolumn{6}{|c|}{ (a) Growth parameters } \\
\hline 1 & Plant height $(\mathrm{cm})$ at 90 DAP & 15.57 & 17.67 & 77.7 & 28.27 \\
\hline 2 & Number of primary branches (90 DAP) & 19.6 & 24.44 & 64.3 & 32.36 \\
\hline 3 & Number of secondary branches (90 DAP) & 33.97 & 45.76 & 55.1 & 51.96 \\
\hline 4 & Number of leaves per plant (90 DAP) & 70.95 & 71.92 & 97.3 & 94.78 \\
\hline 5 & Plant spread in E-W (cm) (90 DAP) & 21.21 & 22.8 & 86.6 & 40.66 \\
\hline 6 & Plant spread in N-S (cm) (90 DAP) & 16.95 & 20.17 & 70.7 & 29.35 \\
\hline 7 & Leaf area $\left(\mathrm{cm}^{2}\right)$ & 32.66 & 33.95 & 92.6 & 64.73 \\
\hline 8 & Stem girth (mm) & 22.6 & 23.29 & 94.2 & 45.19 \\
\hline \multicolumn{6}{|c|}{ (b) Flowering parameters } \\
\hline 1 & Days to first bud initiation & 21.05 & 21.09 & 99.74 & 43.18 \\
\hline 2 & Days to first flowering & 21.03 & 21.16 & 99.43 & 43.34 \\
\hline 3 & Days to $50 \%$ flowering & 18.94 & 19.02 & 99.6 & 38.78 \\
\hline 4 & Duration of flowering (days) & 14.38 & 14.97 & 96.02 & 27.89 \\
\hline \multicolumn{6}{|c|}{ (c) Yield parameters } \\
\hline 1 & Number of flowers/plant & 29.75 & 30.38 & 95.9 & 60.02 \\
\hline 2 & Flower yield/plant (g) & 24.76 & 26.12 & 89.9 & 48.36 \\
\hline 3 & Flower yield per ha (t) & 24.77 & 26.13 & 89.9 & 48.06 \\
\hline \multicolumn{6}{|c|}{ (c) Quality parameters } \\
\hline 1 & Individual flower weight (g) & 25.74 & 26.36 & 95.4 & 51.8 \\
\hline 2 & Weight of 100 flowers (g) & 25.76 & 26.38 & 95.3 & 53.5 \\
\hline 3 & Flower diameter $(\mathrm{cm})$ & 14.76 & 15.12 & 95.3 & 28.69 \\
\hline 4 & Shelf life (hours) & 21.36 & 22.01 & 94.2 & 42.72 \\
\hline
\end{tabular}




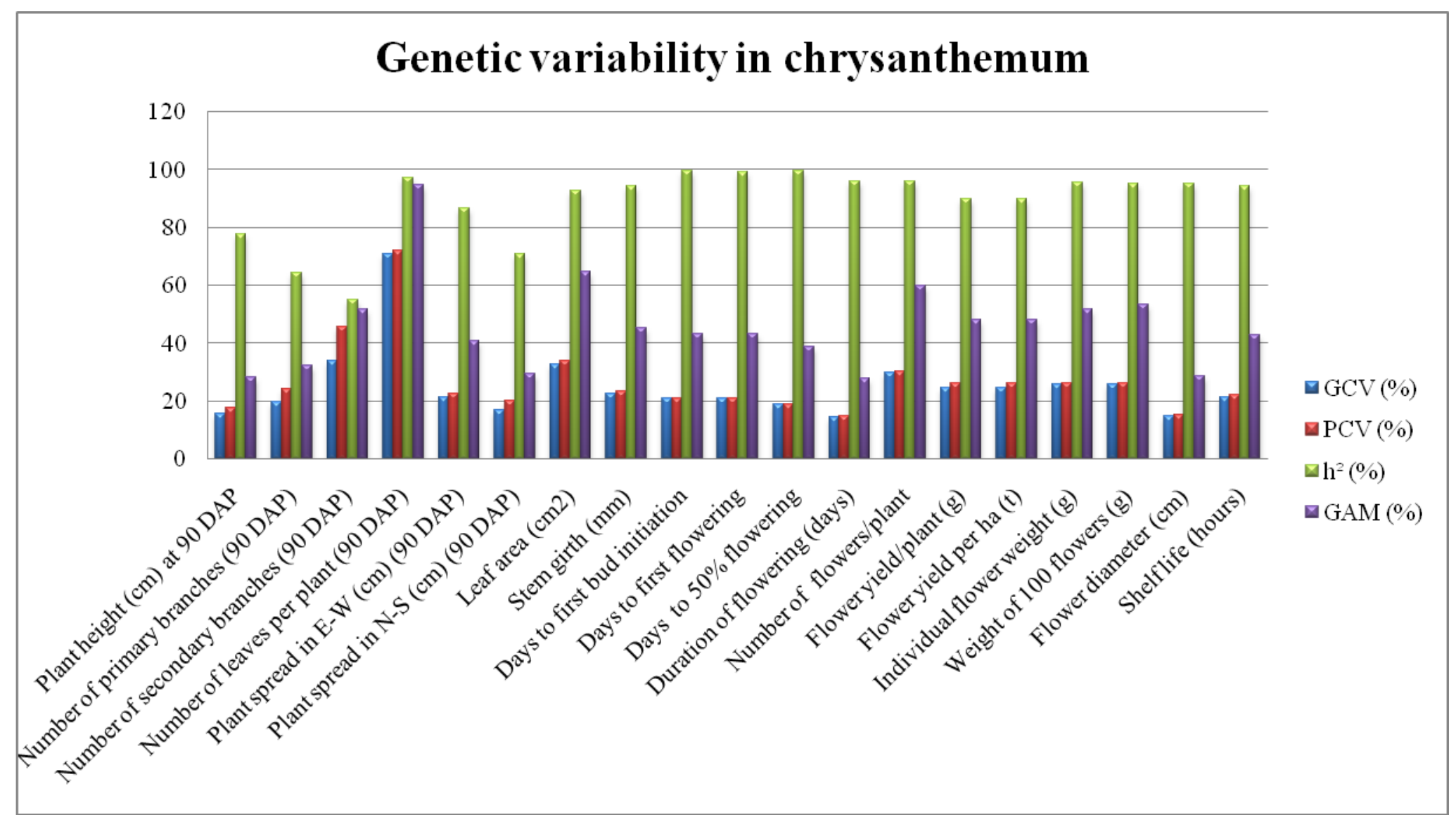

Fig.1 The graph showing genetic variability in chrysanthemum genotypes 
High estimates of GCV (21.03\%) and PCV $(21.16 \%)$ coupled with high heritability (99.43\%) and high genetic advance as per cent of mean $(43.34 \%)$ observed for days taken to first flowering. Moderate estimates of GCV (18.94\%) and PCV (19.02\%) coupled with high heritability $(99.60 \%)$ and high genetic advance as per cent of mean $(38.78 \%)$.

Moderate estimates of GCV (14.40\%) and PCV (14.80\%) coupled with high heritability $(96.02 \%)$ and high genetic advance as per cent of mean $(27.89 \%)$ were recorded for flowering duration in chrysanthemum.

Significant variations were observed for flowering parameters, indicating the wide variability present among the genotypes. The phenotypic coefficient of variability (PCV) was higher than the genotypic coefficients of variability $(\mathrm{GCV})$ for the flowering characters studied. Similar results were obtained by Chaugale (1985) and Shiragur (2009) in chrysanthemum and Naik et al., (2004) in China aster.

It is obvious because PCV embodies variability due to genotypes, environment and genotype $\mathrm{x}$ environment interaction. The differences among the phenotypic coefficients of variations and genotypic coefficients of variations were very less for leaf area, days to flower bud initiation, days taken for first flowering, days to 50 per cent flowering and duration of flowering indicating that, the flowering nature of chrysanthemum is more of genetically controlled, as it is short day plant i.e less role of environment or contribution of genetic variability towards total variance similar trend shown by Sathian (2015) in chrysanthemum and Kore (2014) in China aster. It may be concluded that these are the characters in chrysanthemum breeding programme for effective utilization of the existing variability.
Similarly high heritability coupled with high genetic advance over per cent mean was exhibited for days taken for first flowering, days taken for 50 per cent flowering and duration of flowering, which indicating the predominance of additive components.

Thus direct selection helps in improving the characters. Similar results were obtained by Raghav and Negi (1994) in China aster for duration of flowering in African marigold by Kishore and Raghava (2001) for days taken for 50 per cent flowering.

\section{Yield parameters}

The genotypic coefficients of variations $(29.75 \%)$ and phenotypic coefficients of variations $(30.38 \%)$ were high for number of flowers. Heritability was high $(95.90 \%)$ with high genetic advance as per cent of mean $(60.02 \%)$.

Flower yield per plant (g) showed high estimates of GCV (24.76\%) and PCV $(26.12 \%)$ coupled with high heritability $(89.90 \%)$ and high genetic advance as per cent of mean $(48.36 \%)$.

The variability estimates for flower yield per hectare (t) showed high GCV (24.77\%) and PCV (26.13\%) coupled with high heritability $(89.90 \%)$ and genetic advance as per cent of mean of $(48.06 \%)$.

The yield parameters also exhibited high genetic variability for most of the characters indicating the adequate amount of genetic variability existed in the material. Sufficient genetic variability which can be exploited by selection. However, the difference among phenotypic coefficient of variation and genotypic coefficient of variation was very less indicating the contribution of genetic variability to the total variability. Similar results were obtained by Janakiram and Rao 
(1991) for total flower yield per plant in African marigold and Shiragur (2009) in chrysanthemum.

In the present investigation, high heritability estimates associated with high genetic advance was noticed for number of flowers per plant, flower yield per plant and flower yield per hectare indicating the role of additive gene action. Similar results reported by Chaugule (1985), Chezhiyan et al., (1985); Barigidad (1992); Sirohi and Behera (2000) and Talukdar et al., (2003) and Sathian (2015) in chrysanthemum; Mathew et al., (2005); Singh and Saha (2006); Singh et al., (2008) and Kavitha and Anburani (2010) in marigold. Overall yield and yield contributing characters have exhibited high genetic variability coupled with moderate GA, indicating the scope for further improvement.

\section{Quality parameters}

High estimates of GCV (25.74\%) and PCV $(26.36 \%)$ were coupled with high heritability (95.40\%) and high genetic advance as per cent of mean $(51.80 \%)$ were observed for individual flower weight.

High estimates of GCV (25.76\%) and PCV $(26.38 \%)$ were coupled with high heritability (95.30\%) and high genetic advance of 53.50 per cent of mean were observed for hundred flowers weight. The genotypic coefficient of variation (14.76\%) and phenotypic coefficient of variation (15.12\%) were moderate for flower diameter. High heritability of 95.3 per cent of mean was coupled with moderate genetic advance of 28.69 per cent of mean recorded for this trait.

Shelf life showed high estimates of GCV $(21.36 \%)$ and PCV (22.01\%) coupled with high heritability $(94.20 \%)$ and moderate genetic advance as per cent of mean $(42.72 \%)$
For quality parameters, the ANOVA indicates high significant difference. Phenotypic coefficient of variation was higher than genotypic coefficient of variation. High estimates of heritability associated with high genetic advance were observed for hundred flower weight, single flower weight and flower diameter. Similar results were obtained in chrysanthemum for flower diameter by Barigidad (1992) and Sirohi and Behera (2000).

Improving flowering parameters are ultimate goal in the breeding programme; they need a wide range of variability for the important characters. In present investigation, wide variability was observed for important characters like stem girth, diameter of flower and number of flowers per plant. Hence, careful selection may be practiced for improving the characters through hybridization followed by selection.

Analysis of Variance showed significant differences among genotypes for all the characters studied. Results revealed that magnitude of the Phenotypic Coefficient of Variation (PCV) was higher than Genotypic Coefficient of Variation (GCV) for all the traits, indicating genotype and environment interaction. High (>20\%) PCV and GCV was observed for number of secondary branches, number of leaves, leaf area, stem girth, days to flower bud initiation and days to first flowering. Heritability estimates ranged from a moderate $55.10 \%$ (number of secondary branches/plant) to high as $99.74 \%$ (Days to flower bud initiation). High heritability $(>60 \%)$ was observed for all traits except number of secondary branches/plant. Estimates of high heritability coupled with high genetic advance as per cent of mean (GAM) were observed for all the growth, flowering, yield and quality parameters studied indicating the possible role of additive gene action. 


\section{References}

Anonymous, 2016, Area and production database, Dept. of Horticulture, Govt. of Karnataka.

Barigidad, H., Patil, A. A. and Nalawadi, U. G., 1992, Variability studies in chrysanthemum. Prog. Hort., 24 (1-2): 55-59.

Burton, G. W. and Dewane, E. M., 1953, Estimating heritability from replicated clonal material. Agron. J., 45: 478-481.

Chaugule, B. B., 1985, Studies on genetic variability in chrysanthemum (Chrysanthemum morifolium). M. Sc. (Agri) Thesis, Mahatma Phule Agril. Univ., Rahuri.

Chezhiyan, N., Ponnuswami, V., Thamburaj, S., Khader, J. M. A., Nangan, K. and Gunashekaran, N., 1985, Evaluation of chrysanthemum cultivars. South Ind. Hort., 33: 279-282.

Hanson, W. D., 1963, Heritability. Symp. Statist. Genet. Pt. br., Raleigh, Cardina, pp: 425-430.

Janakiram, T. and Rao, T. M., 1991, Genetic improvement of marigold. In Floriculture Technology, Trade and Trends. Ed. Prakash, J and Bhandary, K. R., Oxford and IBH Company Private Limited, New Delhi, pp. 331335.

Johnson, H. W., Robinson, H. F. and Comstock, R. E., 1955, Estimates of genetic and environmental variability in soyabeans. Agron. J., 47: 314-318.

Kannan, M. and Ramdas, S., 1990, Variability and heritability studies in gerbera. Prog. Hort., 22: 72-76.

Kavitha, R and Anburani, A., 2010, Genetic variability in African marigold (Tagetes erecta L.). Asian. J. Hort. 5 (2): 344346.

Kishore, N. and Raghava, S. P. S., 2001, Variability studies in African marigold
(Tagetes erecta L.). J. Orn. Hort, New Series, 4 (2): 124-125.

Kore, R., 2014, Studies on genetic variability and molecular characterization in China aster (Callistephus chinensis [L.] Nees.). M. Sc. (Hort.) Thesis. UHS Bagalkot.

Kumbar, I., Patil, C. P., Kulkarni, B. S., Shiragur, M. and Shirol, A. M., 2017, Efficacy of Entrophospora sp. (VA Mycorrhiza) on salt tolerance and flower yield and quality of chrysanthemum var. Marigold (Dendranthema grandiflora Tzvelev). Int.J.Curr.Microbiol.App.Sci. $\quad$ 6(10): 4769-4777.

Mathew, R., Hatia, S. K., Beniwal, B. S. and Deswal, D. P., 2005, Correlation and path analysis in flower production and seed yield in marigold. National symposium on recent trend and future strategies. Orn. Hort. pp: 105-108.

Naik, B. H., Basavaraj, N. and Patil, V. S., 2004, Correlation studies in China aster (Callisthephus chinensis Ness.) genotypes. J. Orn. Hort., 7(3-4) 81-86.

Negi, S. S., Ragava, S. P. S., Sharma, T. V. R. S. and Sreenivasan, R. R., 1983, Studies on variability and correlation in China aster. Indian J. Hort, 40: 102-106.

Panse, V. G. and Sukhatme, P. V., 1967, Statistical methods for agricultural workers, ICAR. New Delhi.

Raghava, S. P. S. and Negi, S. S., 1994, Genetic analysis of various quantitative traits in China aster (Callisthephus chinensis Ness.). Indian J. Hort. 51(1): 106-110.

Robinson, H. F., Comstock, R. E. and Harvey, P. M., 1949, Estimates of heritability and degree of dominance in corn. Agron. J., 41: 353-359.

Sathian, L., 2015, Morphological and molecular characterization of chrysanthemum (Dendranthema 
grandiflora Tzelev) genotypes. M. Sc (Hort.) Thesis. UHS Bagalkot.

Shiragur, M., 2009, Characterization of chrysanthemum (Dendranthema grandiflora Tzvelev.) germplasm through morphological and molecular markers, Ph. D Thesis Univ. Agril. Sci., Bangalore.

Singh, K. P. and Saha, T. N., 2006, Genetic variability, heritability and genetic advance in French marigold (Tagetes patula L.). Ind J. Pla. Gen. Res., 19(2): 42-43.
Singh, K. P., Raju, D. V. S., Prasad, K. V. and Bharadwaj, C., 2008, Studies on genetic variability, heritability and genetic advance in French marigold (Tagetes patula L.). J. Orn. Hort., 12 (1): 30-34.

Sirohi, P. T. and Behera T. K., 2000, Genetic variability in chrysanthemum. J. Orn. Hort., (New series), 3(1): 34-36.

Talukdar, M. C., Mahanta, S., Sharma, B. and Das, S., 2003, Extent of genetic variation for growth and floral characters in chrysanthemum cultivars under Assam condition. J. Orn. Hort., 6(3): 201-211.

\section{How to cite this article:}

Mallikarjun Hebbal, Mukund Shiragur, Mahantesha B.N. Naika, G.K. Seetharamu, Sandhyarani Nishani and Patil, B.C. 2018. Assessment of Genetic Variability, Heritability and Genetic Advance in Chrysanthemum (Dendranthema grandiflora Tzvelve). Int.J.Curr.Microbiol.App.Sci. 7(08): 4544-4553. doi: https://doi.org/10.20546/ijcmas.2018.708.481 